\title{
Adaylık Eğitimi Uygulama Sürecinin Aday Öğretmenlerin Görüşlerine Göre İncelenmesi
}

\author{
Doç. Dr. Salih Akyıldız ${ }^{1}$ \\ Doç. Dr. Taner Altun ${ }^{2^{*}}$ \\ Şengül Kasım ${ }^{3}$
}

Geliş tarihi: 04.12.2019

Kabul tarihi: 01.01.2020

\section{Atıf bilgisi:}

IBAD Sosyal Bilimler Dergisi

Sayı: $6 \quad$ Sayfa: $117-131$

Yıl: 2020 Dönem: Kış

This article was checked by iThenticate. Similarity Index 10\%

Bu makalede yayın ve araştırma etiğine uyulmuştur.

${ }^{1}$ Trabzon Üniversitesi, Türkiye, sakvildiz61@gmail.com

ORCID ID 0000-0002-8569-7411

${ }^{2 *}$ Trabzon Üniversitesi, Türkiye, taltun@,trabzon.edu.tr

ORCID ID 0000-0001-9946-7257

3 Trabzon Üniversitesi, Türkiye, sengulkasim@hotmail.com ORCID ID 0000-0003-0241-7531

* Sorumlu yazar öz

Bu araştırmanın amacı, Milli Eğitim Bakanlı̆̆ı bünyesinde çeşitli okullarda göreve başlayan aday öğretmenlerin adaylık eğitimi süreci ile ilgili görüşlerini incelemektir. Çalışma nitel araştırma yaklaşımı çerçevesinde yürütülmüş olup durum çalışması yöntemi kullanılmıștır. Araștırmanın çalıșma grubunu, 2015-2016 eğitim öğretim yllında, Milli Eğitim Bakanlığı tarafından başlatılan "Aday Öğretmenlerin Yetiștirilme Süreci" uygulamasına Trabzon il merkezinde katılan 100’ü kadın, 21’i erkek olmak üzere toplam 121 aday ögrretmen oluşturmaktadır. Araştırmada veriler yarı-yapılandırılmış ve açık uçlu sorulardan olușan yazılı görüs alma anketi ile toplanmıștır. Bu ham veriler daha sonra içerik analizi yöntemiyle analiz edilmiştir. Araştırmanın bulgularına göre aday öğretmen yetiştirme sürecinde okul yöneticileri ve danışman öğretmenlerin aday öğretmenlere yardımcı olma açısından yeterince bilgilendirilmediği, bu nedenle bazı sorunlar yașandığı tespit edilmiștir. Katılımcılar danıșman öğretmenlerini mesleki olarak donanımlı bulmalarına karşın sınıfa aday öğretmenlerle birlikte girmelerinin öğrenci gözünde aday öğretmenlerin imajını düşürdüğü sonucuna ulaşılmıştır. Çalışma sonunda aday öğretmen yetiștirme sürecinin kalitesinin artırılmasına yönelik çeșitli önerilerde bulunulmuştur.

Anahtar Kelimeler: aday öğretmen, adaylık eğitimi, öğretmen yetiştirme. 


\title{
Evaluation of Teacher Candidacy Training Process Based on Candidate Teachers' Views
}

\author{
Assoc. Prof. Dr. Salih Akylddız \\ Assoc. Prof. Dr. Taner Altun ${ }^{2^{*}}$ \\ Şengül Kasım ${ }^{3}$
}

First received: 04.12.2019

Accepted: 01.01.2020

\section{Citation:}

IBAD Journal of Social Sciences

Issue: 6

Pages: 117-131

Year: 2020

Session: Winter

This article was checked by iThenticate. Similarity Index 10\%

\footnotetext{
${ }^{1}$ Trabzon University, Turkey, sakyildiz61@gmail.com ORCID ID 0000-0002-8569-7411

$2^{*}$ Trabzon University, Turkey, taltun@,trabzon.edu.tr

ORCID ID 0000-0001-9946-7257

${ }^{3}$ Trabzon University, Turkey, sengulkasim@hotmail.com
} ORCID ID 0000-0003-0241-7531

* Corresponding Author

\begin{abstract}
The aim of this study is to investigate the views of candidate teachers who started to work in various schools belong to Ministry of National Education about new teacher candidacy training practice. The study was conducted within the qualitative research approach and case study method was utilized. Study group consists of 100 female and 21 male total 121 candidate teachers who joined to "Candidate Teacher Training Process" which was initiated by the Ministry of National Education in 2015-2016 academic year in Trabzon city. The data of the study were collected through a questionnaire consisting of semi-structured and open-ended questions. Obtained raw data was analysed by employing content analysis. According to findings despite school managers and mentor teachers were eager to help candidate teachers due to lack of information some problems were aroused during candidate teacher training process. Participants of the study found mentor teachers adequately equipped however, it was determined that mentor teachers' presence in the class with candidate teachers was an image breaker for candidates in terms of students' perspectives. At the end of the study some suggestions were made in order to improve the quality of candidate teacher training process.
\end{abstract}

Anahtar Kelimeler: teacher candidates, candidacy training, teacher education 


\section{GİRIŞ}

Eğitim sisteminin temel bileşenlerinden biri hiç kuşkusuz öğretmendir. Çağın gerektirdiği bilgi ve donanıma sahip, eleştirel düşünebilen, soran ve sorgulayan, öğrenmeyi öğrenmiş, kendisi ve çevresi ile barışık ve toplumun ihtiyaç duyduğu niteliklere sahip bireylerin yetiştirilmesi öğretmenlere bağlıdır. Öğretmen, eğitim sisteminin diğer bileșenlerinin ișe koșulmasından ve öğretim hizmetinin niteliğinden sorumludur. Bu nedenle öğretmen yetiştirme süreci, nitelikli öğretmen yetiştirme açısından son derece önemli bir süreçtir. $\mathrm{Bu}$ süreç, hizmet öncesi eğitim, adaylık dönemi eğitimleri ve hizmet içi eğitimleri kapsamaktadır.

Mesleğe yeni başlayan bir öğretmen, her ne kadar nitelikli bir hizmet öncesi eğitim almış olsa da, uygulamadaki farkl1l1klar, meslekteki ilk deneyim heyecanı, mesleğe uyum sorunları gibi etkenlerden dolayı, mesleğin ilk yıllarında kapsamlı bir rehberliğe ihtiyaç duymaktadır (Yalçınkaya, 2002). Zira, Başar ve Doğan (2015)'a göre: "Mesleğin ilk yllında sorun yaşayan aday ögretmenler, mesleki inançlarını ve motivasyonlarını kaybederek gerekli verimi sağlayamamakta ve karşılaş̧ıkları sorunları nasıl çözeceklerini bilememektedir." (s.376).

Öğretmenlerin adaylık dönemi, "öğretmen adayının mesleğe hazırlanmasında pratik değeri olan ve adayın uygulama ile en yoğun şekilde buluştuğu bir süreç" (Ekinci, 2010: 64) olarak görülmektedir. Her meslekte olduğu gibi öğretmen adaylarının da öğrencilikten öğretmenlik mesleğine geçişlerinde ilk yıl güçlükler yaşanır. Öğretmenlerin hizmet öncesinde aldıkları öğretmenlik eğitimi, bu yeni koşullara uyum sağlama ve karşılaştıkları güçlükleri aşmada gerekli bilgi ve beceriyi kendilerine sağlayamaz. $\mathrm{Bu}$ nedenle, meslekte ilk y1l "başarma veya kırılma zamanı" olarak görülmektedir (Kozikoğlu, 2016). Nitekim bu konuda yapılan araştırmalar, üniversiteden yeni mezun olmuş öğretmen adaylarının okul çevresi ve ortamına ve ilk görevine alışma konusunda güçlükler yaşadıklarını göstermektedir (Korkmaz, 1999; Yalçınkaya, 2002; Korkmaz ve Akbaşl1, 2004; Erdemir, 2007; Öztürk, 2008; Duran, Sezgin ve Çoban, 2011; Gömleksiz, Kan, Biçer ve Yetkiner, 2010; Sarı ve Altun, 2015; Başar ve Doğan, 2015; Kozikoğlu, 2016).

Calderhead (1997), öğretmenler için memuriyete başlamayı yalnızca bir okula geçme olayı olarak değil, aynı zamanda öğretmenlik mesleğinin belli değerlerini benimseme olarak görmektedir (Aktaran: Çelik, 1998). Bu amaçla, kurumlarda yeni gelenlere yetiștirme programları uygulanmaktadır. $\mathrm{Bu}$ program kapsamında, deneyimli danışman (koç, mentor, rehber), yeni gelene iş ile ilgili bilgiler vermekte ve işyeri ile ilgili norm ve değerler kazandırılmakta ve kişi kuruma uyumlu hale getirilmeye çalışılmaktadır (Memduhoğlu, 2008).

Türkiye'de aday memurların yetiştirilmesine ilişkin ilk kapsamlı uygulama 1995 ve 2015 yılları arasında yapılmıştır. Yapılan araştırmalar, bu adaylık eğitimi programının öğretmenlerin gereksinimlerini karşılama, amaç ve içerik bakımından yetersiz olduğunu göstermiştir (Özonay, 2004; Çimen, 2010; Y1ldırım, 2010; Ayvaz Düzyol, 2012). Daha sonra yapılan değişiklikle, 2015-2016 öğretim yılından itibaren aday öğretmenlerin yetiştirilmesinde farklı bir yaklaşım benimsenmiştir. Bakanlığın 2 Mart 2016 tarihinde yayımladığı yönerge ile aday öğretmenlere adaylıklarının ilk ayında, görevlendirildikleri okullarda okul müdürü ve danışman öğretmenin sorumluluğunda, işe başlama eğitimi almalarına karar verilmiştir. Bu eğitim, sınıf ve okul içi, okul dışı faaliyetler ile hizmet-içi eğitim seminerlerinden oluşmaktadır (MEB, 2016b). Aday öğretmenler yetiştirme sürecinde, 384 saat sınıf içi ve okul içi, 90 saat okul dışı faaliyetleri, 180 saat hizmet-içi eğitim faaliyetleri olmak üzere toplam: 654 saat eğitim verilmesi planlanmaktadır (MEB, 2016a).

Aday öğretmen yetiştirme süreci, kapsamı bakanlıkça tespit edilen bir program dahilinde aday öğretmenlerin Milli Eğitim Müdürlüklerince görevlendirildikleri okul veya kurumlarda, o kurumun veya okulun idarecileri ve danışman öğretmenlerinin rehberliğinde uygulanmaktadır. Yetiştirme süreci sonunda aday öğretmenlerin performansları değerlendirilmektedir (MEB, 2016a). Aday öğretmenler, Bakanlık tarafından yapılacak yazılı ve sözlü sınava girebilme şartı olarak en az bir yıl fiilen çalışmak ve performans değerlendirmesine göre başarılı olmak zorundadırlar (MEB, 2015).

Aday öğretmenin yetişme sürecinde, il ve ilçe milli eğitim müdürleri, maarif müfettişi, eğitim kurumu müdürü ve danışman öğretmenlerin çeşitli görev ve sorumlulukları bulunmaktadır (MEB, 2015; 2016b). 
Okul veya kurum müdürünün, öncelikle danışman öğretmen görevlendirerek aday öğretmenlerin çalışma programını birlikte planlama, çalışma programında yapılması planlanan etkinliklerin sağlıklı yürütülmesi için gereken önlemleri alma, aday öğretmeni bu süreçte, çeşitli mesleki değerlendirme kriterleri açısından gözlemleme ve bütün bu süreçlerde kendisine rehberlik etme gibi çeşitli görevleri mevcuttur. Aynı şekilde danışman öğretmen aday öğretmeni bu kurumdaki etkinliklerinde yine mesleki kriterler açısından gözlemler, rehberlik sağlar ve değerlendirir (MEB, 2015). Bunun yanında, okul müdürü veya idareciler ile birlikte aday öğretmenlerin çalışma programını planlama, planlanma etkinliklerin yararlı olması için adaylara yardımcı olma ve destek sağlama ve buna yönelik çeşitli önlemler alma, aday öğretmenlerin programın hedeflerine uygun yetişmelerini izleme, onları değerlendirme ve onlara rehberlik yapma ve aday öğretmenlere mesleki bilgi, beceri, tutum ve davranışlarıyla örnek olma ve tecrübelerini gibi farklı görevleri de bulunmaktadır (MEB, 2016b).

Adaylık eğitimi ile öğretmenliğe yeni başlayan öğretmen adayının hem çalışacağ de mesleğine uyumunun sağlanması, karşılaştığı güçlüklerle baş edebilmesi amaçlanmaktadır. Bu çalışma ile mesleğe yeni başlayan öğretmenlerin, adaylık eğitimi süreci ile ilgili tespit edilen görüş ve önerilerinin, adaylık eğitim süreci daha etkin ve verimli şekilde nasıl düzenlenebilir sorusuna cevap bulmada kolaylık sağlayabileceği düşünülmektedir. Ayrıca, adaylık eğitim sürecinin iyileştirilmesi ve etkin bir şekilde yürütülmesi, öğretmenlerin mesleki ve kurumsal bağlılıklarını artıracağı söylenebilir.

\section{Araştırmanın Amacı}

Araştırmanın temel amacı, Millî Eğitim Bakanlı̆̆ı'nda göreve yeni atanan aday öğretmenlerin adaylık eğitimi sürecine ilişkin görüşlerini belirlemektir. $\mathrm{Bu}$ amaç doğrultusunda çalışmada aşağıdaki sorulara cevaplar aranmıştır:

1. Aday öğretmenlerin adaylık eğitimi sürecine yönelik bakış açıları nelerdir?

2. Adaylık eğitimi sürecinde okul ve sınıf içinde karşılaşılan genel problemler nelerdir?

3. Adaylık eğitimi sürecinde verilen hizmet-iç eğitim faaliyetlerine yönelik aday öğretmenlerin düşünceleri nelerdir?

\section{YÖNTEM}

$\mathrm{Bu}$ araştırma nitel araştırma yaklaşımı içerisinde tasarlanmış olup çalışmada nitel araştırma desenlerinden özel durum çalışması yöntemi kullanılmıştır. Özel durum yönteminde genel olarak güncel olgu, olay, durum, birey ve gruplar daha derinlemesine incelenmeye çalış1lır (Ekiz, 2009). Nitel araştırma yaklaşımı, "gözlem, görüşme ve doküman analizi gibi nitel veri toplama yöntemlerinin kullanıldlğgl, alglların ve olayların doğal ortamda gerçekçi ve bütüncül bir biçimde ortaya konmasına yönelik nitel bir sürecin izlendiği araştırma" şeklinde tanımlanmaktadır (Yıldırım ve Şimşek, 2013). Bu araştırma, Millî Eğitim Bakanlığı'nın uygulamaya koyduğu adaylık eğitimi kapsamında Trabzon ilindeki okullarda adaylık eğitimini tamamlayan aday sınıf öğretmenlerinin adaylık eğitim süreci ile ilgili görüş ve değerlendirmelerini, aday öğretmenlerin deneyimlerine dayalı olarak onların sürece yönelik görüş ve düşüncelerini daha derinlemesine incelemeyi amaçladığı için çalışma nitel yaklaşım çerçevesinde yürütülmüştür.

\section{Çalışma Grubu}

$\mathrm{Bu}$ araştırmada çalışma grubu, nitel araştırma kapsamındaki örnekleme yöntem çeşitlerinden olan homojen örnekleme yolu ile belirlenmiştir. Bu örnekleme yöntemiyle, bir olay olgu hakkında geniş ve zengin bilgilere erişilebileceği düşünülen durumlar daha detaylı ve derinlemesine incelenebilir (Büyüköztürk vd., 2012; Yıldırım ve Şimşek, 2013). Tanımlanmış ve belirli özelliklere sahip kişilerin seçilerek araştırmaya dâhil edilmesi ise homojen örnekleme tekniği olarak ifade edilmektedir (Ekiz, 2009). Araştırmanın çalışma grubunu, 2015-2016 eğitim öğretim yılında, Milli Eğitim Bakanlığı tarafindan başlatılan Trabzon il merkezinde "Aday Öğretmenlerin Yetiştirilme Süreci" uygulamasına katılan 100 kadın, 21 erkek olmak üzere 121 aday öğretmen oluşturmaktadır. 


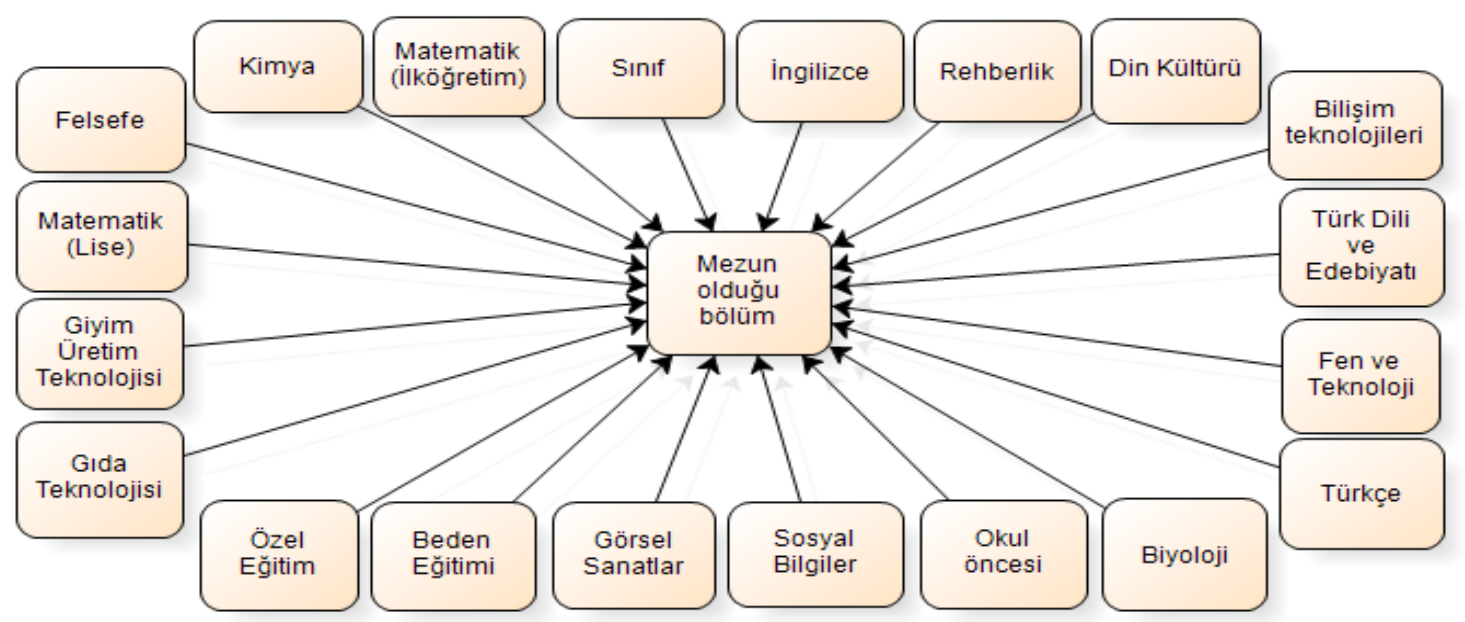

Şekil 1. Aday ögretmenlerin mezun olduğu bölümlere ilişkin bilgiler

Şekil 1'e bakıldığında aday öğretmenlerden 18'i matematik (ilköğretim), 18'i sınıf, 11'i İngilizce, 10'u rehberlik, 9'u din kültürü, 7'si bilişim teknolojileri, 6'sı Türk dili ve edebiyatı, 5'i fen ve teknoloji, 4'ü Türkçe, 4'ü biyoloji, 3'ü okul öncesi, 2'si sosyal bilgiler, 2'si görsel sanatlar, 2'si beden eğitimi, 2'si özel eğitim, 1'i gida ve teknolojisi, 1'i giyim ve üretim teknolojisi, 1'i matematik (lise), 1'i felsefe ve 1'i de kimya öğretmenliği alanlarından mezun olmuşlardır. Bunun dışında 7 aday öğretmen görüşme formunda diğer seçeneğini işaretlerken 6'sı ise branşını belirtmemiştir.

\section{Veri Toplama Araçları}

Trabzon il merkezindeki ilkokullarda adaylık eğitimini tamamlayan öğretmen adaylarına adaylık eğitimi sonunda adaylık süreci ile ilgili görüş ve değerlendirmelerini almak amacıyla yarı yapılandırılmış ve açık uçlu sorulardan oluşan bir anket uygulanmıştır. Ankette yer alan açık uçlu sorulardan bazıları şöyledir:

1. Uygulama okulunuza ilişkin görüşleriniz nelerdir?

2. Okullarda yaptığınız "Ders içi gözlem” uygulaması ilgili görüşleriniz nelerdir?

3. Danışman öğretmeninize ilişkin görüşleriniz nelerdir? (Rol modelliği, bilgisi, deneyimi, teknoloji kullanımı, sınıf yönetimi vb.)

4. Aday öğretmenlerin yetiştirilme süreci kapsamında düzenlenen hizmet içi eğitim faaliyetleri ile ilgili görüşleriniz nelerdir?

5. Performans değerlendirme uygulaması ile ilgili görüşleriniz nelerdir? nelerdir?

6. Genel olarak, "Aday Öğretmenlerin Yetiştirilme Süreci” ile ilgili başka görüş ve önerileriniz

Araştırmacılar tarafindan geliştirilen bu formun hazırlanmasında konu alanı uzmanı ve dil uzmanlarından görüş alınmış, çalışma kapsamı dışındaki üç öğretmenle de pilot uygulama yapılarak anket sorularına nihai şekli verilmiştir.

Öğretmen adaylarının görüşlerini daha rahat ifade edebilmelerini sağlamak amacıyla anketlere isimlerini yazmamaları istenmiştir. Veri toplama formundaki sorular açık uçlu sorulardan oluşturulmuştur. Bu tip sorular katılımcıya esnek bir şekilde cevap verme olanağı sağladığı gibi kapalı uçlu sorulara göre katılımcıları daha çok motive eder (Balc1, 1997). Diğer yandan bu tip sorular hem araştırmacıya esneklik sağlar hem de konuyla ilgili önemli değişkenlerin göz ardı edilmemesine yardımcı olur (Yıldırım ve Şimşek, 2013). 


\section{Verilerin Analizi}

Anketlerle yazılı olarak alınan veriler içerik analizi yöntemine tabi tutularak incelenmiştir. İçerik analizi yönteminde nitel verilerin oluşturduğu bir metindeki sözcükler çeşitli kriterlere göre kodlanarak çeşitli kategoriler ve temalar elde edilir (Büyüköztürk vd., 2012; Ekiz, 2009). Bu analiz tekniğinin amacı, elde edilen ham verilerden yola çıkarak bu verileri anlamlandıracak çeşitli kavramlara ulaşmak ve bu kavramlar arasındaki ilişkileri açıklamaktır (Yıldırım ve Şimşek, 2013).

$\mathrm{Bu}$ çalışmada verilerin analizi NVIVO-9.2 programı kullanılarak gerçekleştirilmiş̧ir. Anket formunda yer alan her bir soruyla ilgili elde edilen veriler için kodlamalar yapılmış, bunlardan tema ve alt temalara gidilmiş ve her temaya ilişkin elde edilen veriler analiz edilmiştir. NVIVO analizi sonucu edilen kavramsal kategoriler şemalar halinde şekillendirilmiş ve bu şemalar katılımcıların yazdıkları cevaplardan doğrudan alıntılarla desteklenmiştir (Ekiz, 2009).

\section{BULGULAR}

Millî Eğitim Bakanlığı tarafından "aday öğretmenlerin yetiştirilme süreci" uygulamasına yönelik aday öğretmenlerden elde edilen bulgular üç bölümde incelenmiştir. İlk bölümde aday öğretmenlerin okul ve sınıf içi faaliyetlerle ilgili görüşlerine, ikinci bölümde okul dışı faaliyetlerle ilgili görüşlerine ve son bölümde ise uygulama hakkında genel görüşlerine yer verilmiştir.

\section{A. Okul ve Sınıf İçi Faaliyetler}

Görüşme formunun ilk bölümünde aday öğretmenlerin okul ve sınıf içi faaliyetlere ilişkin görüşlerinin neler olduğu tespit edilmeye çalışılmıştır. Bu amaçla görüşme formunun birinci bölümünde yer alan üç soru aday öğretmenlere sorulmuştur.

\section{Uygulama okulunun yönetimine ilişkin görüşler}

Aday öğretmenlere ilk olarak uygulama yaptıkları okullara ilişkin görüşlerinin neler olduğu sorusu yöneltilmiştir. Aday öğretmenlerden konu ile ilgili elde edilen görüşler Model 2' de sunulmuştur.

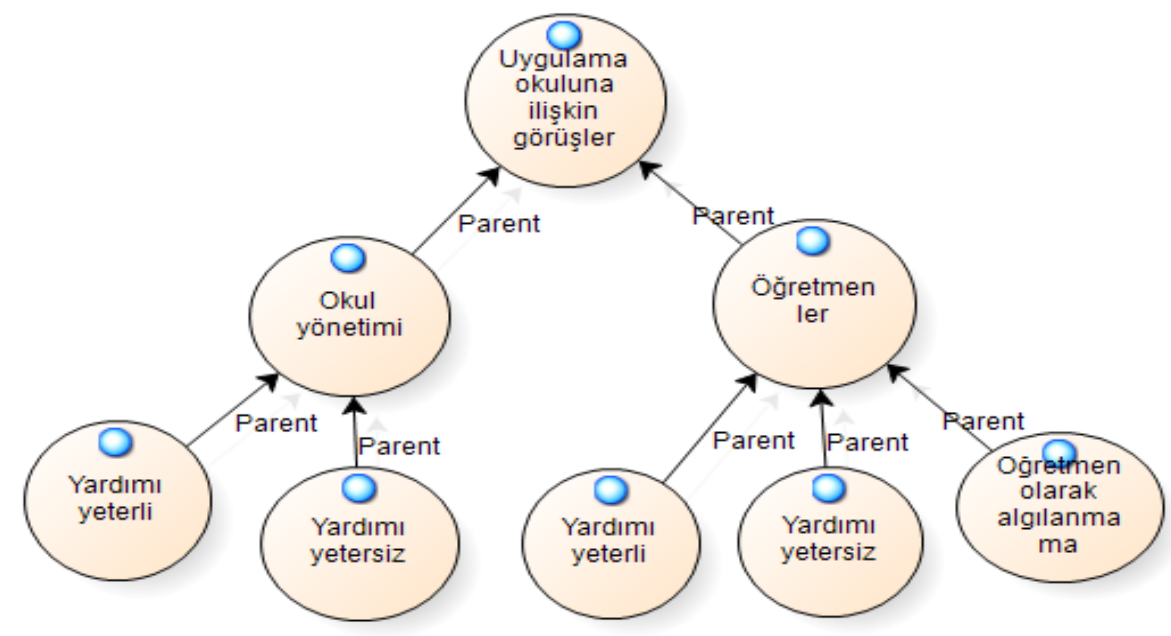

Şekil 2. Aday öğretmenlerin uygulama okullarına ilişkin görüşleri

Şekil 2 incelendiğinde aday öğretmenler uygulama okullarını okul yönetimi ve okulda görev yapan öğretmenler açısından değerlendirmişlerdir. Okul yönetimi ile ilgili değerlendirme yapan aday ögretmenlerden 47'si okul yönetimi yardımının süreç boyunca yeterli olduğunu vurgulamışlardır. Bu görüşü paylaşan aday öğretmenlerden AÖ100 şunu ifade etmiştir; "Okul yönetimi süreçten haberdar değildi. Karşılaştı̆̆ım bir sorunu söylediğimde onların da bilmediği ortaya çıkıyordu. Ama hiçbir soruma cevapsiz kalmadılar. Başka idarecileri ya da milli eğitimi arayarak her seferinde bana yardımcı oldular. Okulda diğer ögretmenlere davranıldiğg gibi davrandılar." 
Aday öğretmenlerin 23'ü ise okul yönetimi yardımlarının yetersiz kaldığını belirtmişlerdir. AÖ1 konuya yönelik "Okul yönetimi bilgilendirme, yardımcı olma ve sorumlulukları yerine getirme noktasında çok gerideydi. Aday öğretmenleri unutmuş, kendi işleriyle meşguldüler. Umarım bundan sonra daha iyi olur." Şeklinde görüşünü ifade etmiştir.

Uygulama okullarında görev yapan öğretmenlere yönelik değerlendirme yapan aday öğretmenlerden 78'i öğretmenlerin yardımını yeterli bulduklarını belirtmişlerdir. Bu görüşü paylaşan aday öğretmenlerden AÖ119 şunu ifade etmiştir:

"Bizlere son derece içten davranmışlardır. Gerek önceki yillarda edindikleri gerekse aday ögretmenlik sürecinde bizlerin şahit olduğu tecrübelerini her yönüyle kkulağımıza küpe olması' amacıyla bizlerle paylaşmışlardır. Danışman ögrretmenimizin dışında farklı branşlarda gerçekleştirmek istediğimiz gözlemler için teklifte bulunduğumuz tüm öğretmenler son derece yardimsever davranmişlar ve derslerinde gözlem yapmamıza müsaade etmişlerdir."

Aday öğretmenlerin 27'si öğretmenler tarafindan öğretmen olarak algılanmadıklarını ve stajyer muamelesi gördüklerini ileri sürmüştür. AÖ102 konuya yönelik "Danışman ögretmenler bazı durumlarda bizi evrak yükü olarak gördü. Bu durumun sonucunda da bizi mesai arkadaşl gibi değil de stajyer gibi görüp muamele etti." şeklinde görüşünü dile getirmiştir.

\section{Ders içi gözlem uygulamalarının etkililiğine ilişskin görüsşler}

Aday öğretmenlere ikinci soru olarak uygulama yaptıkları okullarda "Ders içi gözlem" uygulamasına yönelik görüşlerinin neler olduğu sorulmuştur. Aday öğretmenlerden konu ile ilgili elde edilen görüşler Şekil 3'te sunulmuştur.

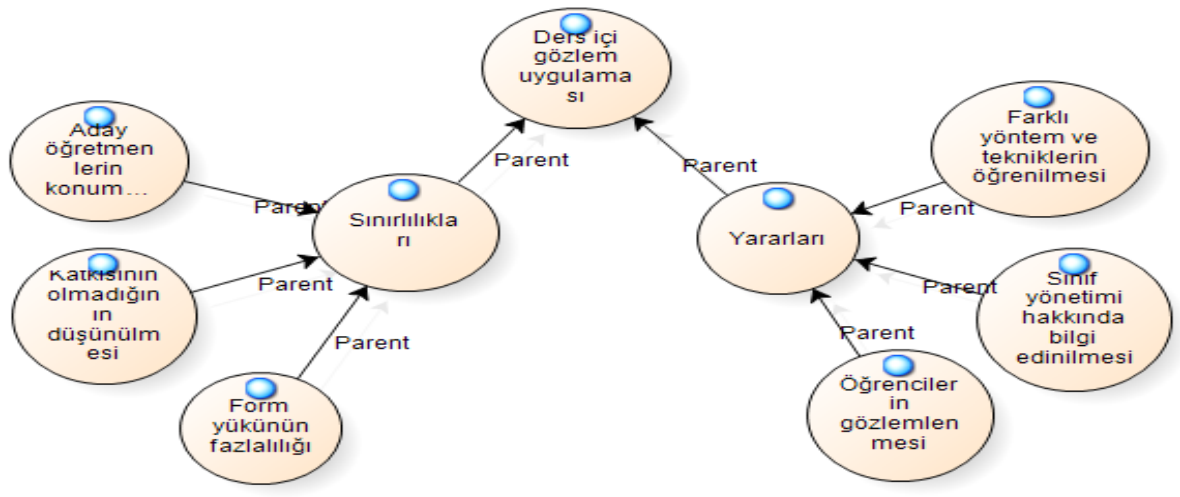

Şekil 3. Aday öğretmenlerin ders içi gözlem uygulamasına ilişkin görüşleri

Şekil 3 incelendiğinde aday öğretmenler ders içi gözlem uygulamasına ilişkin görüşlerini belirtirken uygulamanın sınırlılıklarına ve yararlarına değinmişlerdir. Uygulamanın sınırlılıklarına değinen öğretmenlerden 61 'i danışman öğretmenin sınıfa kendileriyle beraber girmesi nedeniyle davranışlarında kısıtlanma hissettiklerini, kendilerinin öğrenci gözünde öğretmen olarak algılanmalarında problem yaşadıklarını bu nedenle sınıfa hâkimiyet kurmada zorlandıklarını vurgulamışlardır. Bu görüşü paylaşan aday öğretmenlerden AÖ48 şunu ifade etmiştir; "Sinıfta danışma olması bizimle ögrenciler arasındaki iletişimde ögrencilerin öncelikle danışmanı benimsemeleri açısından hâkimiyetimize sınır getirdi."

Aday öğretmenlerden $15^{\prime} \mathrm{i}$ süreç boyunca kendilerinden doldurulması istenilen formların fazla olmasından yakınmışlandır. AÖ8 konuya yönelik "Açıkçası ders esnasında form yazmaktan ders gözlemini çoğu zaman kaçırdı̆̆ım oldu. Formlar daha az ve etkili şekilde yerine getirilmelidir." demiştir.

Aday öğretmenlerden 11'i ise ders içi gözlem uygulamasının herhangi bir katkısının olmadığını düşünmektedir. Böyle düşünen aday öğretmenlerden AÖ101 konuyla ilgili düşüncesini şöyle belirtmiştir; "Bence faydalı bir program değildi. Hatta bazı gelen hocalar okul müdürü olmasına rağmen 
"EBA" programının saçma bir program olduğunu düşünüyorlar. Bize verdikleri programın tam olarak ne olduğunu bilincinde bile değiller. Kendi başarılarından ve ailelerinden bahsedip seminer yaptıklarını zannediyorlar."

Ders içi gözlem uygulamasının yararlarından bahseden aday öğretmenlerden 60'^ uygulama sayesinde sınıf yönetimi hakkında bilgi edindiklerini belirtmişlerdir. AÖ10 şunu ifade etmiştir;

"Gerektiğinde yapmam gerektiğinden yapmamam gereken davranışları görmem açısından faydalı olduğunu düşünüyorum." Aday öğretmenlerden 28'i öğrenci davranışlarını gözlemleme firsatı yakaladıklarını ifade etmişlerdir. AÖ̈106 konuya yönelik "Öğrenci davranışların izleme firsatımız olmuştur" demiştir. 28'i ise sınıf içerisinde gözlem yaparak farklı yöntem ve teknikler hakkında bilgi sahibi olduklarını vurgulamışlardır. Bu görüşü paylaşan aday öğretmenlerden AÖ30 şunu ifade etmiştir; "Danışman hocamızın ders sunumlarında uyguladığ yeni yöntem/ teknik vb. uygulamaları görme firsatı bulmamız güzeldi." şeklinde belirtmiştir.

\section{Danışman öğretmenin niteliği}

Aday öğretmenlere üçüncü soru olarak danışman öğretmenleri ile ilgili izlenimlerinin neler olduğu sorusu yöneltilmiştir. Aday öğretmenlerden konu ile ilgili elde edilen bulgular Şekil 4'te sunulmuştur.

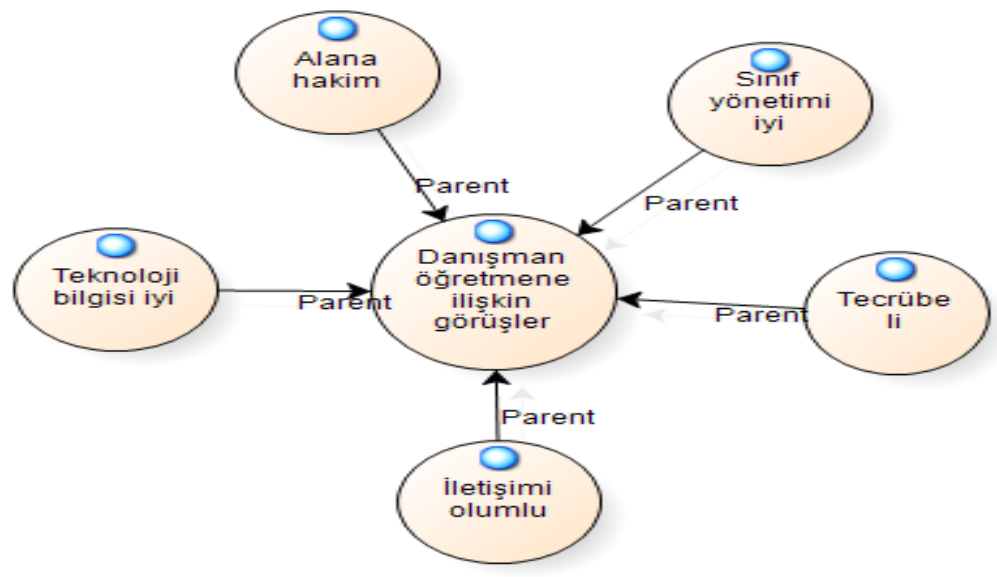

Şekil 4. Aday öğretmenlerin danışman öğretmenlere yönelik izlenimleri

Şekil 4'e bakıldığında aday öğretmenlerden 68'i danışman öğretmenlerinin alana hâkim olduğunu, 58'i mesleki bakımdan tecrübeli bulduklarını ifade etmişlerdir. Diğer taraftan 53'ü danışman öğretmeninin iletişim ş̧eklini olumlu bulurken, 43'ü sınıf yönetimini iyi sağladığını, 30'u ise teknolojiyi iyi kullandığını belirtmişlerdir. Bu görüşü paylaşan aday öğretmenlerden AÖ13 konuya ilişkin şu sözleri ifade ederken; "Danışman öğretmenim bu süreçte bana gerçekten yardımcı oldu. Bilgisi, deneyimi, mesleki ve kişisel yaşantısıyla rol model oldu diyebilirim. Sinuf yönetimi, ögrencilerle iletişimi gayet iyiydi." AÖ18 ise düşüncelerini; "Danışman ögrretmenim alanında çok iyi olan ögretmenlerden bir tanesiydi. Sinıf yönetimi, bilgisi, dersi işleyişi, farklı kaynaklar ve teknoloji kullanımı çok iyiydi. Bir konuyu her şekilde bol örneklerle vermeye çalışır mutlaka çalışma kâğıtları hazırlar. EBA'yı etkin şekilde kullanıyordu. Toplantı tutanakları, dosya düzeni de iyiydi. Düzenli bir şekilde faydalanabilmeme yardımcı oldu. Belirli gün ve haftalara göre etkinlikler planlar ve sık sık geziler yapmaya çalışırdl. Ben adaylık sürecinde etkili bir kazanım sağladığını düşünüyorum. Danışman öğretmenimden çok memnundum. Öğretmenim birçok deneyimini benimle paylaştı ve ön hazırlıklar yapmama vesile oldu." şeklinde ifade etmiştir.

\section{B. Okul Dışı Hizmet-İçi Faaliyetler}

Görüşme formunun ikinci bölümünde uygulama kapsamında aday öğretmenlerin okul dışı hizmet-içi faaliyetlerle ilgili görüşlerinin neler olduğu öğrenilmeye çalışılmıştır. $\mathrm{Bu}$ amaçla görüşme formunun ikinci bölümünde bu alt amaca yönelik bir soru yöneltilmiştir. 


\section{Hizmet-içi eğitim etkinliklerine iliş̧kin görüşler}

Aday öğretmenlerden yetiştirilme süreci kapsamında düzenlenen hizmet içi eğitim faaliyetleri ile ilgili görüşlerini söylemeleri istenmiştir. Aday öğretmenlerden elde edilen veriler Şekil 5'te sunulmuştur.

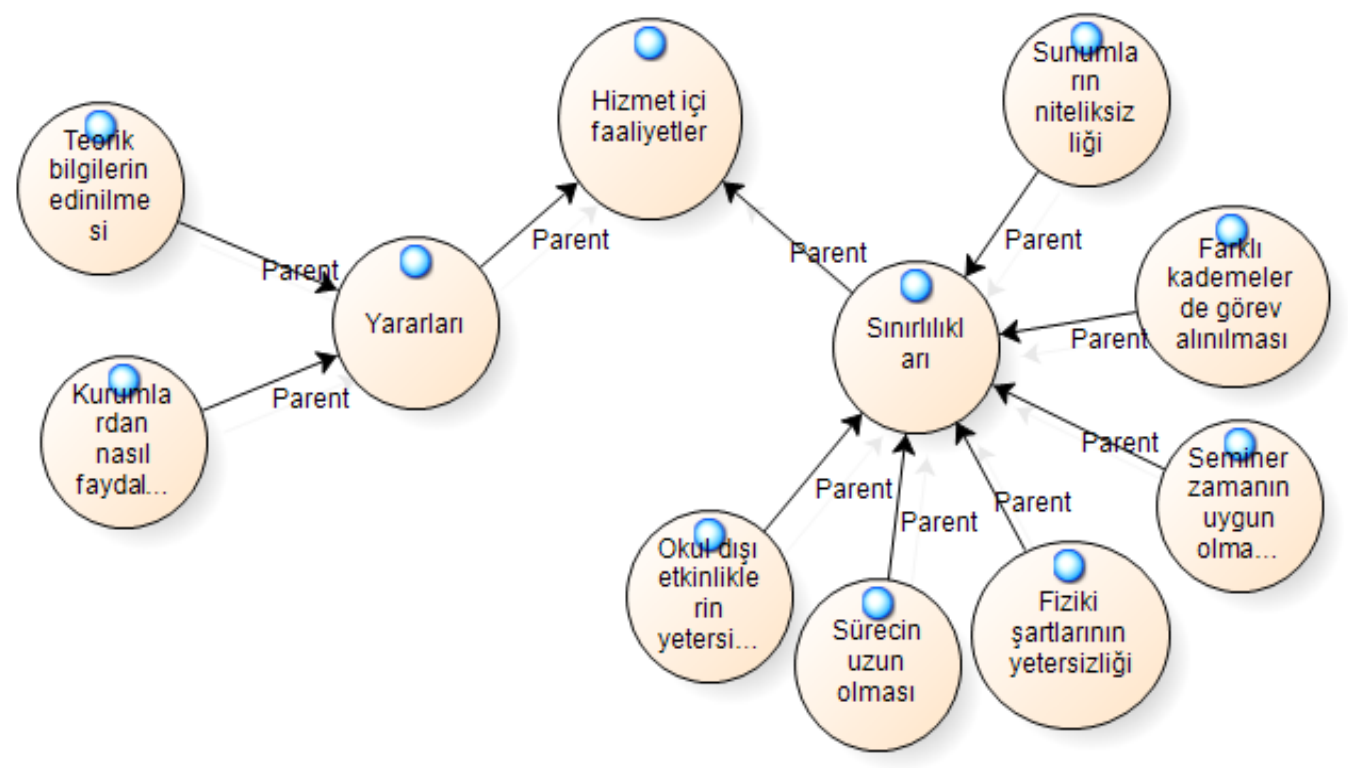

Şekil 5. Aday ögretmenlerin hizmet içi eğitim faaliyetlerine ilişkin düşünceleri

Şekil 5' incelendiğinde aday öğretmenlerin kendilerine sunulan hizmet içi eğitim etkinliklerine ilişkin görüşlerini belirtirken eğitimin yararlarına ve sınırlılıklarına dikkat çektikleri görülmektedir. Hizmet içi eğitim faaliyetlerinin yararlı olduğunu söyleyen aday öğretmenlerden 40'1 teorik bilgiler elde ettiklerini, 29'u kurumlardan nasıl șekilde faydalanacaklarını öğrendiklerini dile getirmişlerdir. Teorik bilgiler elde etmede yarar sağladıklarını belirten aday öğretmenlerden AÖ1 "Daha önce bilmediğim bilgiler edindim. Öğretmenlik üzerine daha çok teorik bilgiler oldu." şeklinde ifade ederken kurumlardan nasıl faydalanacağı hakkında bilgi edindiklerini belirten aday öğretmenlerden AÖ11 ise "Okul dışı faaliyette bulunduğum ilçedeki birçok kurumu, yöneticileri, kurumların iş ve işlemleri hakkında birçok şey ögrenmiş oldum." cevabını vermiştir.

Hizmet içi eğitim faaliyetlerinin sınırlılıklarından bahseden aday öğretmenlerden 36's1 süreci uzun bulduklarını vurgulamışlardır. Bu görüşü paylaşan aday öğretmenlerden AÖ107 düşüncesini şu şekilde ifade etmiștir; "Sürecin daha kısa tutulması kanaatindeyim. Sürecin ikinci ayından itibaren kendime güvenimin tamamen yerine geldiğini ve genel olarak sonuna kadar bu şekilde devam ettiğimden dolayı tek başıma derse giremememin gereksiz olduğunu düşünüyorum." 34'ü eğitim aldıkları okullarda fiziki şartların yetersiz olduğunu söylemişlerdir. AÖ83 konuya ilişkin şu sözleri ifade etmiştir; "Ortamdan kaynakl sorunlar vardl. Salonun klimasız oluşu, salonun ışıklandırma sisteminden kaynaklı bir boşluk vs. Seminerlerde sürekli önde oturmaya çalıştım". Aday öğretmenlerden 28'i yapılan sunumları niteliksiz bulduklarını vurgulamışlardır. AÖ6 konuya yönelik "Bazı sunumların verimliliği oldukça düşüktü” demiştir. Aday öğretmenlerin 27'si seminer zamanını uygun bulmadıklarını belirtmişlerdir. $\mathrm{Bu}$ görüşü paylaşan aday öğretmenlerden AÖ15 şunu ifade etmiştir; "Tatile ihtiyacımız olduğu bu dönemde bu semineri aldığımız için yeterince verimli olmadı. Mevsimin yaz olması, bir kısmının ramazana denk gelmesi, uzaktan gidiş geliş yapmamız nedenleriyle yorucu bir süreç geçirdik." Aday öğretmenlerin 16 'sı ise okul dış1 etkinliklerine fazla yer verilmediğini ileri sürmüşlerdir. AÖ46 konuya yönelik "Okul dışı faaliyetler tam anlamıyla gerçekleştirilmediği için pek yararlı bulamadım. ” demiştir.

Son olarak aday öğretmenlerin 11'i ise farklı kademelerde görev aldıkları halde hizmet içi eğitim faaliyetlerinde farklı kademede bulunan öğrencilerle bir araya geldiklerini bu nedenle sürecin kendileri için pek faydalı olmadığını ifade etmişlerdir. AÖ23 konuya ilişkin "Branşımdan dolayı ders içi gözlem 
yapmam çok sınırlı oldu. Ayrıca atandı̆̆ım asıl okul lise olmasına rağmen ilkokulda gözlem yaptım." Şeklinde görüş bildirmiştir.

\section{Uygulama Hakkında Genel Görüsşler}

Görüşme formunun üçüncü bölümünde aday öğretmenlerin uygulama hakkında genel görüşlerinin neler olduğu belirlenmeye çalışılmıştır. $\mathrm{Bu}$ amaçla görüşme formunun üçüncü bölümünde yer alan iki soru aday öğretmenlere yöneltilmiştir.

\section{Performans değerlendirme uygulamasına yönelik görüşler}

Aday öğretmenlere performans değerlendirme uygulaması ile ilgili görüşlerinin neler olduğu sorulmuştur. Aday öğretmenlerden elde edilen veriler Şekil 6'da sunulmuştur.

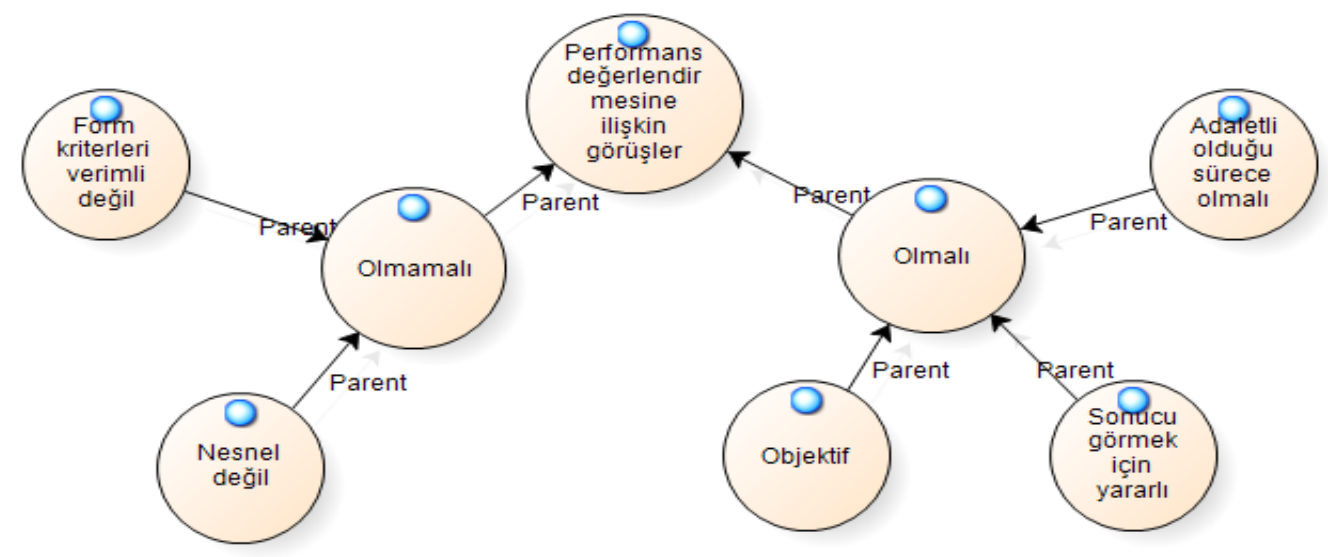

Şekil 6. Aday öğretmenlerin performans değerlendirme uygulaması ile ilgili görüşleri

Şekil 6'da görüldüğü gibi aday öğretmenlerin bir kısmı performans değerlendirme uygulamasının olması gerektiğini savunurken bir kısmı ise olmaması gerektiğini ileri sürmüştür. Uygulamanın olması gerektiğini düşünen aday öğretmenlerden 33'ü değerlendirmenin objektif bir şekilde yapıldığına inandıklarını dile getirmişlerdir. AÖ92 konuya yönelik "Görev yaptığım okulda ilk 6 haftası sınıf içi görülen 7. ve 16. haftalar arası ders içi uygulamalarda bulunduğum sürece branşımın gerekliliklerini yerine getirmeye çalıştım. Gerek danışman ögrretmenimin gerek okul müdürümün süreç içerisindeki hakkım oldukları değerlendirmeyi verdiklerine hiç şüphem yok." söylemiştir. Aday öğretmenlerin 18'i sonucu görmek açısından uygulamayı yararlı bulduklarını ifade etmişlerdir. Bu görüşü paylaşan aday öğretmenlerden AÖ110 şunu ifade etmiştir; "Geri bildirim açısından fayda sağladı. Eksiklerimizi görmemizi sağladı." 9'u ise uygulamanın adaletli olduğu sürece olması gerektiğinin altını çizmiştir. AÖ6 ise konuya "Güvenilir kişilerce yapıldı̆̆ında gayet verimli olacağına inanıyorum." cevabını vermiştir.

Aday öğretmenlerin 27'si uygulamayı nesnel bulmadıklarını ve onlara verilen formlarda yer alan kriterlerin uygun olmadığını ileri sürmüşlerdir. Uygulamayı nesnel bulmayan aday öğretmenlerden AÖ107 şunu belirtmiştir; Kriterli bir formun doldurulması objektifliği sağlamayı çalışsa da çoğu danışmanın hakkiyla doldurmadiğını düşünüyorum. Okulumda sadece sabah gelip akşam giden adayların projeden projeye koşturan adaylardan daha fazla puan aldığını ögrrendim. O adaylardan düşük puan almak gerçekten verdiğim emeklerin karşıllğını alamadı̆̆ düşünmeme sebep oldu”. Form kriterlerinin verimli olmadığını söyleyen AÖ5 ise konuya ilişkin; "Performans değerlendirmelerinde çok gerçekçi davranılmadığı kanaatindeyim. Çünkü değerlendirmede kullanılan belli başlı bazı kriterleri uygulayabilmemiz için uygun ortam ve zemin bulamamaktaydık. Bu gibi durumlarda bazı ögretmenlerimiz bunlara tam verirken bazıları ise bunlardan puan kırdı. Böylece aynı çalı̧̧maları yapan iki aday öğretmen arasinda fark oluştu ve bu moral bozukluğuna da yol açtı. Bu konuda değerlendirme kriterlerini biraz daha farklılaştırarak değerlendirmeye farklı ölçütleri katmak daha doğru olabilir diye düşünüyorum." Şeklinde görüş bildirmiştir. 


\section{Aday öğretmenlerin sürece yönelik önerileri}

Aday öğretmenlere "Aday Öğretmenlerin Yetiştirilme Süreci” ile ilgili başka görüş ve önerilerin olup olmadığı sorulmuştur. Aday öğretmenlerden elde edilen bulgular Şekil 7'de sunulmuştur.

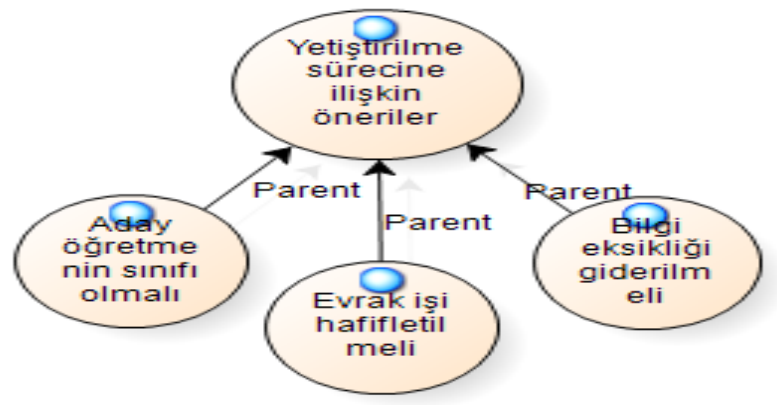

Şekil 7. Aday ögretmenlerin sürece yönelik görüş ve önerileri

Şekil 7'ye bakıldığında aday öğretmenlerin 30'u süreç boyunca doldurulan formların çok fazla olduğunu bu durumun kendilerini geliştirecek çalışma yapmalarını engellediğini vurgulamışlardır. Bu görüşü paylaşan aday öğretmenlerden AÖ106 şunu ifade etmiştir; Süreç boyunca doldurduğumuz formlar da bizim kendimizi geliştirmeye yönelik çalışmalar yapmamızın önüne geçmiştir. Temmuz ayında aldı̆̆ımız seminerlerin bile rapor edilmesini istenmesi bizleri fazlasıyla yormuştur.

Aday öğretmenlerin 28'i yetkili kişilerdeki bilgi eksikliğinin giderilmesi gerektiğini belirtmişlerdir. AÖ81 konuya yönelik "Öğretmen iyi niyetli ve anlayışlıydl. Ancak süreç hakkında bilgilendirmedi. Yanına gittiğimde şaşırmıştı. Danışman ögretmenim olduğunu benden ögrendi. Neler yapılacak ya da neler yapılmayacak onu bu konuda yapılan seminere bile çağırmamışlar. Yarım yamalak bilgilerle işe başladık." demiştir.

Araştırmaya katılan aday öğretmenlerin $10^{\prime} \mathrm{u}$ ise aday öğretmenlerin kendine ait bir sınıfı olması gerektiğini ifade etmiştir; AÖ25 bu konuya yönelik görüşünü "Bu süreci kendi okulumuzda müdür ya da müdür yardımcısı rehberliğinde hâkimi kendi olduğumuz sınıflarda geçirebiliriz. Okul dışı faaliyetler daha gelişstirilmeli, dar bir zaman dilimine sıkıştırılmamalı. Saatlerde esneklik sağlanmal." şeklinde ifade etmiştir.

\section{TARTISSMA SONUÇ VE ÖNERILER}

Milli Eğitim Bakanlığı, mesleğe yeni başlayan aday öğretmenlerin mesleki uyumlarını sağlamak amacıyla "Aday Öğretmen Yetiştirme Eğitimi" adıyla yeni bir uygulama başlatılımıştır. Bu çalışmada, (1) okul ve sınıf içi faaliyetler, (2) okul dışı faaliyetler ve (3) uygulama boyutlarından oluşan aday ögretmenlerin yetiştirilme süreci hakkında aday öğretmenlerin görüşleri incelenmiştir.

Aday öğretmenlerin, okul ve sınıf içi faaliyetler kapsamında, "uygulama okulu", "ders içi gözlem uygulaması" ve "danışman öğretmen" e ilişkin görüşleri araştırılmıştır.

Araştırmada aday öğretmenlerin okul yönetiminden genel olarak destek aldıkları ancak okul yönetimlerinin ve okullardaki öğretmenlerin "aday öğretmenlerin yetiştirilme süreci”" uygulamasına yönelik bilgi düzeylerinin sınırlı olmasından dolayı aday öğretmenlere sağlanan desteğin yetersiz düzeyde kaldığı sonucuna ulaşılmıştır. Okul yönetimi ile ilgili görüş belirten aday öğretmenlerin büyük çoğunluğu, okul yönetiminin süreç boyunca yeterli olduğunu belirtirken, bir kısım aday öğretmenler ise okul yönetiminin yetersiz kaldığını belirtmişlerdir. Okul yönetiminin yetersiz kaldığını belirten aday öğretmenler, okul yönetiminin kendilerine yeterince yardım ve destek sağlamadığı kendilerini yeterince bilgilendirmediklerini idile getirmişlerdir. Aday öğretmenlerin büyük çoğunluğu, okuldaki öğretmenlerin yardımlarını yeterli bulmuşlardır. Öğretmenlerin kendilerine çok içten davrandığını, tecrübelerini paylaşıtılarını ifade etmişlerdir. Aday öğretmenlerin az bir kısmı ise öğretmenlerin kendilerini öğretmen olarak görmediklerini, onlara stajyer muamelesi yaptıklarını ifade etmiştir. Aday öğretmenlerin çok az bir kısmı da öğretmenlerden yeteri derecede yardım alamadıklarına değinmiştir. Elde edilen bulgular 
1şığında aday öğretmenlerin çoğunluğunun okul ve sınıf içi faaliyetlerinde okul yönetimleri ve ögretmenlerin kendilerine olan yardımlarını olumlu buldukları söylenebilir. Adayların olumsuz olarak nitelendirdikleri durumların da okul yönetimleri ve öğretmenlerin yeni adaylık eğitimi süreci hakkındaki bilgilerinin eksikliğinden kaynaklandığı anlaşılmaktadır. SETA, tarafından yapılan kapsamlı bir araştırmaya göre, öğretmenlerin yarıdan fazlası adaylık eğitimini mesleğe hazırlık ve mesleki gelişim bağlamında olumlu bulmuştur (İlyas, Coşkun ve Toklucu, 2017). Diğer benzer araştırmalarda aday ögretmenler, aday öğretmen yetiştirme sürecini olumlu bulduklarını belirtmişlerdir (Çakmak, Kaçar ve Arıkan, 2018; Gökkulu, 2016; Gül, Türkmen ve Aksel, 2017; Tunçbilek ve Tünay, 2017). Bu çalışmanın bulguları da bahsedilen araştırma bulgularıyla paralellik göstermektedir.

Araştırmada, "ders içi gözlem" uygulamasına ilişkin olarak, uygulamanın yararlarından bahseden aday öğretmenlerin yarıya yakın bir kısmı öğrenci davranışlarını gözleme firsatı bulduklarını, yine diğer yarıya yakın bir kısmı gözlem yaparak farklı yöntem ve teknikler hakkında bilgi sahibi olduklarını belirtmişlerdir. Aday öğretmenlerin çok az bir kısmı da sınıf yönetimi hakkında bilgi edindiklerini ifade etmişlerdir. Ders içi gözlem uygulamasının sınırlılıklarına değinen aday öğretmenlerin büyük çoğunluğu ise danışman öğretmenin kendileriyle sınıfa girmelerini olumlu karşılamamış; kısıtlama hissettiklerini, öğrencilerin kendilerini öğretmen olarak görmedikleri için sınıf yönetiminde zorlandıklarını belirtmişlerdir. Aday öğretmenlerin az bir kısmı ders gözlem sırasında doldurmak zorunda oldukları formların fazla olmasından şikâyetçi olmuş, bu durumun gözlem yapmayı engellediğini belirtmişlerdir. Aday öğretmenlerin çok az bir kısmı da gözlem yapmanın kendilerine herhangi bir katkısı olmadığını ifade etmişlerdir. Aday öğretmenler ders içi gözlem faaliyetini; öğrenci davranışlarını gözleme, sınıf yönetimi ve farklı yöntem ve teknikler hakkında bilgi edinme açısından olumlu bulmuşlardır.

Çalışmada, aday öğretmenler "danışman öğretmen" ile ilgili olarak; danışman öğretmenlerin alana hakim olduğunu, mesleki bakımdan tecrübeli olduklarını, kendileriyle iyi iletişim kurduklarını, sınıf yönetimini iyi sağladıklarını ve teknolojiyi iyi kullandıklarını belirtmişleridir. Aday öğretmenler, uygulamada danışman olarak seçilen öğretmenleri, kendileri için birçok alanda yeterli gördükleri anlaşılmaktadır. Aday öğretmenlerin okullardaki danışman öğretmenlerini mesleki açıdan (alan bilgisi, sınıf yönetimi, iletişim becerileri vb....) donanımlı buldukları tespit edilmiştir. Bu bulgu Gül, Türkmen ve Aksel'in (2017) yapmış oldukları çalışmada elde edilen bulgularla örtüşmektedir.

Bu çalışmada ayrıca aday öğretmenlerin, okul dışı faaliyetler kapsamında, "hizmet içi faaliyetler" ile ilgili görüşleri incelenmiştir. Araştırmada aday öğretmenlerin aday öğretmen eğitimi sürecinde kendilerine sağlanan hizmet içi eğitim faaliyetlerini teorik bilgiler edinilmesi (kurumlardan nasıl yararlanılacağ $1 \mathrm{vb} . .$.$) açısından yararlı, uygulama açısından ise eksik buldukları tespit edilmiştir. Aday$ öğretmenler, yetişme süreci boyunca düzenlenen hizmet içi faaliyetlerin olumlu ve olumsuz yönlerine dikkat çekmişlerdir. Hizmet içi faaliyetlerin yararlarına dikkat çeken öğretmen adayları teorik bilgi edindiklerini ve kurumlardan nasıl yararlanacaklarını öğrendiklerini belirtmişlerdir. Adayların büyük bir kısmı ise hizmet içi faaliyetlerin sınırlılıklarından bahsetmiştir. Adaylar, hizmet içi eğitim sürecinin uzunluğundan, seminer yerinin fiziki şartlarının yetersiz olduğundan, sunumların niteliksiz olduğundan, seminer zamanını uygun olmadığından, okul dışı etkinliklere fazla yer verilmediğinden şikayet etmişlerdir. Aday öğretmenlerin ifadelerinden, adaylık eğitimi uygulama süreci kapsamında okul dış1 faaliyetler olarak düzenlenen hizmet içi faaliyetleri çoğunlukla olumlu bulmadıkları anlaşılmaktadır. Benzer şekilde Yılmaz (2017)'da yaptığı çalışmada, aday öğretmenlerin yetiştirilme sürecinde aldıkları hizmet içi eğitimin alanında uzman kişiler tarafından verilmediğini tespit etmiştir. Sarıkaya, Samancı ve Yılar (2017) yaptıkları çalışmada, aday ve danışman öğretmenlerin görüşleri doğrultusunda yaz dönemi seminerlerinin gereksiz görüldüğü ve kaldırılması gerektiği sonucuna ulaşılmıştır. $\mathrm{Bu}$ çalışmanın bulgularına benzer şekilde bir başka çalışmada ise aday öğretmenlerin yetiştirilme süreci kapsamında hizmet içi eğitim faaliyetlerinin yetersiz düzeyde kaldığı anlaşılmıştır (Gökulu, 2016).

Araştırmanın son bölümünde aday öğretmenlerin genel olarak uygulama hakkındaki genel görüssleri kapsamında "performans değerlendirme uygulaması" ve "aday öğretmenlerin yetiştirilme süreci" hakkındaki görüşleri incelenmiştir. Çalışmada ulaşılan sonuçlara göre aday öğretmenlerin bir kısmı performans değerlendirme uygulamasının olması gerektiğini savunurken bir kısmı olmaması gerektiğini savunmaktadırlar. Uygulamanın olması gerektiğini savunan aday öğretmenler, uygulamanın objektif bir şekilde yapıldığını, sonucu görmek açısından yararlı olduğunu, adaletli olduğu sürece olması gerektiğini 
ifade etmiştir. Bir kısım aday öğretmen ise uygulamayı çok objektif bulmadığını, kriterlerin uygun olmadığını ileri sürmüşlerdir. Yeni aday öğretmen yetişme sürecinin geneliyle ilgili görüş belirten aday öğretmenler, doldurulan formların çok fazla olduğundan, uygulama sürecinde görevli kişilerdeki bilgi eksikliğinin giderilmesi gerektiğinden, kendilerine ait bir sınıfların olmasının daha uygun olacağından söz etmişlerdir. Aday öğretmenlerin, yetiştirilme süreci ile ilgili uygulamayı genel olarak olumlu buldukları, ancak doldurulan formların fazla olmasından ve ilgili kişilerin uygulama ile ilgili yeterli bilgiye sahip olmamalarından şikayet etmişlerdir. Bu bulgulara benzer şekilde Çakmak, Kaçar ve Arıkan (2018) tarafından yapılan çalışmada ise, aday öğretmenlerin fazla evrak ve form doldurmaktan şikayetçi oldukları tespit edilmiştir. Benzer şekilde, Kılıç, Babayiğit ve Erkuş (2016), yapmış oldukları çalışmada evrak yükünün çok fazla olduğu sonucuna ulaşmışlardır. Siyaset, Ekonomi ve Toplum Araştırmaları Vakfi (SETA), tarafindan yapılan kapsamlı bir araştırmaya göre, öğretmenlerin yarıdan fazlası adaylık eğitimini mesleğe hazırlık ve mesleki gelişim bağlamında olumlu bulunmuş ancak doldurmak zorunda oldukları formların fazla olmasında şikayetçi olmuşlardır (İlyas, Coşkun ve Toklucu, 2017). Yapılan başka bir çalışmada, Topsakal ve Duysak (2017) hem danışman öğretmenlerin hem de aday ögretmenlerin adaylık süresinde doldurulan evrakların fazlalığından yakındıkları belirtmişlerdir. Gül, Türkmen ve Aksel (2017) tarafından yapılan çalışmada okul yöneticilerinin adaylık sürecine bakışının genellikle olumlu olduğu sonucuna ulaşılmıştır. Genel anlamda bu çalışmada elde edilen bulgular bahsedilen çalışma bulgularıyla benzerlik göstermektedir.

Araştırmadan elde edilen bu sonuçlardan yola çıkarak aşağıdaki öneriler geliştirilmiştir:

- Aday öğretmenlerin eğitimi için belirlenen uygulama okullarında görev yapan okul yönetimi ve danışman öğretmenlere eğitim verilebilir.

- Aday öğretmenlere danışman dâhilinde kendilerine ait bir sınıf verilebilir ve aday öğretmenlerin bu sınıfa belli bir süreden sonra tek başlarına girmeleri sağlanabilir.

- Aday öğretmenlerin üzerindeki evrak yükü hafifletilebilir.

- Aday öğretmenlerin adaylık sürecini geçirdikleri okulun, atandıkları okul ve içinde bulundukları kademenin şartlarına benzer şartlarda olması sağlanabilir.

- Bu konuda daha geniş çaplı örnekleme ulaşılıp aday öğretmenlerin mesleğe yönelik tutumları ve aldıkları adaylık eğitimi süreçleri arasındaki ilişkiler nicel çalışmalarla incelenebilir.

Bilgilendirme/Acknowledgement: Bu çalışma 18-21 Ekim 2017 tarihleri arasında Alanya, Antalya'da düzenlenen 2. Uluslararası Akademik Araştırmalar Kongresi (INES2017)'de sözlü bildiri olarak sunulmuştur.

\section{KAYNAKÇA}

Ayvaz Düzyol, M. (2012). The effectiveness of induction program for candidate teachers. Yayımlanmamış yüksek lisans tezi, Orta Doğu Teknik Üniversitesi, Sosyal Bilimler Enstitüsü, Ankara.

Balcı, A. (1997). Sosyal bilimlerde araştırma yöntem, teknik ve ilkeler. Ankara: Bilgisayar Yayıncılık.

Başar, M. ve Doğan, Z. G. (2015). Göreve yeni başlayan öğretmenlerin yaşadığı sosyal kültürel ve mesleki sorunlar. Route Educational and Social Science Journal, 2(4), 375-398.

Büyüköztürk, Ş., Kılıç Çakmak, E., Akgün, Ö.E., Karadeniz, Ş. ve Demirel, F. (2012). Bilimsel araştırma yöntemleri. Ankara: Pegem Yayınları.

Çelik, V. (1998). Alan dışından gelen sınıf öğretmenlerinin örgütsel sosyalizasyonu. Kuram ve Uygulamada Eğitim Yönetimi, 14(14), 191-208.

Çakmak, Z., Kaçar, T., ve Arıkan, İ. (2018). Sosyal Bilgiler aday öğretmenlerinin aday öğretmen yetiştirme sürecine ilişkin görüşleri. Turkish Journal of Educational Studies, 5(1), 58-82. 
Çimen, G. (2010). İlköğretim aday ögrretmenlerinin yetiştirilmesi sürecinin ilköğretim müfettişleri ve okul müdürlerince değerlendirilmesi: Kırıkkale ili örneği. Yayımlanmamış yüksek lisans tezi, Kırıkkale Üniversitesi, Sosyal Bilimler Enstitüsü, Kırıkkale.

Duran, E., Sezgin, F.ve Çoban, O. (2011). Aday sınıf öğretmenlerinin uyum ve sosyalleşme sürecinin incelenmesi. Dumlupinar Üniversitesi, 31, 465-478.

Ekinci, A. (2010). Aday öğretmenlerin iş başinda yetiştirilmesinde okul müdürlerinin rolü. Dicle Üniversitesi Ziya Gökalp Eğitim Fakültesi Dergisi, 15, 63-77

Ekiz, D. (2009). Bilimsel araştırma yöntemleri. Ankara: Anı Yayıncılık.

Erdemir, N. (2007). Mesleğine yeni başlayan fen bilgisi öğretmenlerinin karşılaştıkları sorunlar ve şikayetleri. Elektronik Sosyal Bilimler Dergisi, 6(22), 135-149

Gökulu, A. (2016). Aday öğretmenlerin Türkiye'deki aday öğretmenlik eğitim süreci ile ilgili görüşleri. International Journal of Social Sciences and Education Research, 3(1), 111-123.

Gömleksiz, N., Kan, A. Ü., Biçer, S., ve Yetkiner, A. (2010). Mesleğe yeni başlayan sınıf öğretmenlerinin yaşadıkları zorluklarla öğretmen adaylarının yaşayabilecekleri zorluklara ilişkin algılarının karşılaştırılması. E-Journal of New World Sciences Academy, 5(3), 12-23.

Gül, İ., Türkmen, F., ve Aksel, N. (2017). Aday öğretmen görüşlerine göre aday öğretmen yetiştirme sürecinin değerlendirilmesi. Hitit Üniversitesi Sosyal Bilimler Enstitüsü Dergisi, 10, 365-388.

İlyas, İ. E., Coşkun, İ. ve Toklucu, D. (2017). Türkiye'de aday öğretmen yetiştirme modeli izleme ve değerlendirme. SETA Raporu. Ankara: SETA Yayınları.

K1lıç, D., Babayiğit, Ö., ve Erkuş, B. (2016). Aday öğretmenlerin adaylık eğitimine ilişkin görüşleri. Ekev Akademi Dergisi, 20(68), 81-91.

Korkmaz, S. (1999) Göreve yeni başlayan öğretmenlerin mesleğe uyum sorunları. Yayınlanmamış yüksek lisans tezi, Kocaeli Üniversitesi Sosyal Bilimler Enstitüsü, Kocaeli.

Korkmaz, İ., ve Akbaşlı, S. (2004). Göreve yeni başlayan sınıf öğretmenlerinin karşılaştıkları güçlükler. Kuram ve Uygulamada Eğitim Yönetimi, 38(38), 266-277.

Kozikoğlu, İ. (2016). Öğretimin ilk yıll: mesleğin ilk yılındaki öğretmenlerin karşılaştıkları güçlükler, hizmet öncesi eğitim yeterlikleri ve mesleğe adanmışlıkları. Yayımlanmamış doktora tezi. Yüzüncü Yıl Üniversitesi Eğitim Bilimleri Enstitüsü Eğitim Programları ve Öğretim Anabilim Dali, Van.

MEB (2015). Millî Ĕgitim Bakanlı̆̆ Öğretmen Atama ve Yer Değiștirme Yönetmeliği. 17 Nisan 2015 tarih ve 29329 sayıll Resmi Gazete.

MEB (2016a). Aday öğretmen yetiştirme programi. 11/07/2016 tarihinde http://oygm.meb.gov.tr/www/aday-ogretmen-yetistirmesurecine-iliskinyonerge-ve-yetistirmeprogrami/icerik/328 adresinden erişildi.

MEB (2016b). Aday Öğretmen Yetiştirme Sürecine İlişkin Yönerge. 02.03.2016 tarihli ve 2456947 sayılı Makam Oluru İle yürürlüğe girmiştir.

Memduhoğlu, H., B. (2008). Örgütsel sosyalleşme ve Türk Eğitim Sisteminde örgütsel sosyalleşme süreci. Yüzüncü Yıl Üniversitesi, Eğitim Fakültesi Dergisi, 5(2),137-153.

Özonay, İ.Z. (2004).Öğretmenlerin adaylık eğitimi programının değerlendirmesi. XIII. Ulusal Eğitim Bilimleri Kurultayı, İnönü Üniversitesi, Malatya.

Öztürk, M. (2008). Induction into teaching: Adaptation challenges of novice teachers. Yayınlanmış yüksek lisans tezi, ODTÜ Sosyal Bilimler Enstitüsü, Ankara.

Sarı, M. H., ve Altun, Y. (2015). Göreve yeni başlayan sınıf öğretmenlerinin karşılaştıkları sorunlar. Hacettepe Üniversitesi Eğitim Fakültesi Dergisi, 30(1), 213-226. 
Sarikaya, İ., Samancı, O., ve Yılar, Ö. (2017). Aday öğretmen yetiştirme sürecinin aday ve danışman sınıf öğretmenlerinin görüşleri kapsamında değerlendirilmesi: Bir karma yöntem çalışması. Gazi Üniversitesi Gazi Ĕ̈itim Fakültesi Dergisi, 37(3), 939-989.

Topsakal, C. ve Duysak, A. (2017). Aday öğretmen yetiştirme sürecine ilişkin aday öğretmenler ve diğer paydaşların görüşleri. Sakarya University Journal of Education, 7(3), 625-638.

Tunçbilek, M. M.,ve Tünay, T. (2017). MEB aday öğretmen yetiştirme süreci uygulamasının ilgili tarafların bakış açısıyla değerlendirilmesi. Elektronik Sosyal Bilimler Dergisi, 16(61), 412-427.

Yalçınkaya, M. (2002). Yeni öğretmen ve teftiş. Milli Eğitim Dergisi, 150, 153-154.

Yildırım, Z. Ş. (2010). Evaluation of novice teacher training program: Şanluurfa example. Yayımlanmamış yüksek lisans tezi, Marmara Üniversitesi, Sosyal Bilimler Enstitüsü, İstanbul.

Yıldırım, A. ve Şimşek, H. (2013). Sosyal bilimlerde nitel araştırma yöntemleri. Ankara: Seçkin Yayıncilik.

Yılmaz, M. (2017). Aday öğretmen yetiştirme sürecinde karşılaşılan sorunlar ve çözüm önerileri. 21 . Yüzyılda Eğitim ve Toplum, 6(16), 135-156. 